\title{
Pengaruh Manajemen Laba terhadap Stock Return dengan Kualitas Audit dan Efektivitas Komite Audit sebagai Variabel Moderasi
}

\author{
Aisyah Istiqomah ${ }^{1}$, Desi Adhariani ${ }^{1}$ \\ ${ }^{1}$ Departemen Akuntansi, Fakultas Ekonomi dan Bisnis, \\ Universitas Indonesia, Depok, Indonesia \\ Email: aisyah.isti@gmail.com; desi.adhariani@ui.ac.id
}

\begin{abstract}
ABSTRAK
Penelitian ini bertujuan untuk menganalisis pengaruh manajemen laba terhadap imbal hasil saham (stock return), dengan kualitas audit dan efektivitas komite audit sebagai variabel pemoderasi. Manajemen laba diukur dengan akrual diskresioner menggunakan model Modified Jones. Stock Return diukur dengan menggunakan imbal hasil saham kumulatif. Kualitas audit diproksi dengan variabel dummy Big 4 atau non Big 4; dan efektivitas komite audit diukur dengan jumlah rapat yang dilakukan dalam satu tahun. Penelitian ini dilakukan dengan sampel perusahaan manufaktur yang terdaftar pada Bursa Efek Indonesia untuk periode 2012-2014. Hasil penelitian menunjukkan bahwa manajemen laba memiliki pengaruh negatif terhadap imbal hasil saham. Kualitas audit dan efektifitas komite audit ditemukan mampu memperlemah hubungan negatif tersebut, yang mengindikasikan bahwa kedua mekanisme pengawasan tersebut berfungsi dengan baik dalam memitigasi dampak negatif manajemen laba terhadap imbal hasil saham.
\end{abstract}

Kata kunci: Manajemen laba; imbal hasil saham; kualitas audit; efektivitas komite audit.

\begin{abstract}
This study aims to analyze and provides empirical evidence about the effect of earnings management on stock return with audit quality and the effectiveness of audit committee as the moderating variables. Earnings management is measured by discretionary accruals, estimated using the cross-sectional Modified Jones Model. Audit quality is measured by dummy variable of audit firm size, Big 4 or Non-Big 4; and the effectiveness of audit committee is measured by the number of audit committee meetings held in one year. The sample of this study is manufacturing companies listed in the Indonesia Stock Exchange in 2012-2014. The results of this study show that earnings management negatively affect stock return, and audit quality and the effectiveness of audit committee can moderate the relationship of earnings management with stock return. This results indicate that the two monitoring mechanisms work effectively to mitigate the deteriorating effect of earnings management to stock return.
\end{abstract}

Keywords: Earnings management; stock return; audit quality; effectiveness of audit committee.

\section{PENDAHULUAN}

Dalam membuat keputusan untuk berinvestasi seorang investor membutuhkan informasi yang akurat dan berkualitas untuk dapat melakukan analisis investasi saham di pasar modal, dan salah satu sumber informasi yang digunakan untuk melakukan analisis investasi adalah laporan keuangan yang dikeluarkan oleh perusahaan. Dalam menyusun laporan keuangan, Standar Akuntansi Keuangan menyatakan bahwa mana- jemen dapat memilih dan menerapkan kebijakan akuntansi yang sesuai dengan standar yang berlaku. Standar akuntansi yang ditetapkan berdasarkan prinsip (principle based) membuat manajemen dapat menggunakan penilaiannya sendiri dalam menentukan perlakuan akuntansi atas suatu kejadian ekonomi. Perbedaan antara peraturan atau standar yang berlaku dengan praktiknya sering terjadi di dalam perusahaan, perbedaan ini digunakan untuk memodifikasi laporan keuangan, sehingga laporan keuangan 
dapat menyajikan laba sesuai dengan keinginan dari manajemen perusahaan. Tindakan memodifikasi laporan keuangan sehingga sesuai dengan keinginan dari manajemen dikenal sebagai earnings management.

Kasus earnings management bukanlah permasalahan baru dalam dunia bisnis. Beberapa kasus besar earnings management telah banyak terjadi misalnya kasus Enron pada tahun 2001 dan kasus Worldcom pada tahun 2002. Di Indonesia kasus earnings management juga bukan merupakan hal baru, beberapa kasus earnings management telah terjadi misalnya saja kasus Kimia Farma pada tahun 2002 dan Great River Garment pada tahun 2003. Dengan terungkapnya banyak kasus earnings management (manajemen laba) yang dilakukan oleh perusahaan, membuat para pembuat kebijakan semakin memperketat peraturan atau kebijakan yang ada untuk melindungi para pengguna laporan keuangan.

Manajemen laba sendiri dapat didefinisikan sebagai tindakan pemilihan kebijakan akuntansi untuk mencapai beberapa tujuan pelaporan earnings tertentu (Scott 2011). Praktik manajemen laba memiliki dua sifat utama, yaitu bersifat efisien dan oportunistik. Manajemen laba yang bersifat efisien akan meningkatkan kualitas informasi keuangan yang diterbitkan perusahaan sedangkan manajemen laba yang bersifat oportunistik akan dapat merugikan para pengguna laporan keuangan karena membuat laporan keuangan tidak menggambarkan kondisi sebenarnya (Scott 2011). Manajemen laba yang bersifat oportunistik berkaitan erat dengan permasalahan keagenan (agency problem). Beberapa motivasi dilakukannya manajemen laba adalah untuk memaksimalkan bonus, memenuhi persyaratan kontrak utang, dan motivasi politik (Watts and Zimmerman 1986). Motivasi lainnya adalah untuk menghindari pajak dan mempengaruhi kinerja saham dalam jangka pendek (Scott 2011).

Tindakan manajemen laba yang bersifat oportunistik dapat mengurangi keandalan informasi keuangan yang dikeluarkan perusahaan. Praktik manajemen laba pada umumnya dapat dilakukan dengan pola taking a bath, income minimization, income maximization dan income smoothing (Scott 2011). Penelitian sebelumnya yang telah dilakukan oleh Teoh, Welch dan Wong (1998) dan Nuryaman (2013) menemukan bahwa manajemen laba berhubungan negatif terhadap return saham. Namun hasil berbeda ditunjukkan pada penelitian yang dilakukan oleh DuCharme, Malatesta, dan Sefcik (2004) dan Teoh dan Wong (1993) yang menemukan tidak terdapat pengaruh signifikan manajemen laba terhadap return saham. Penelitian lainnya yang dilakukan oleh Ferdiansyah dan Purnamasari (2012) justru menemukan hubungan positif antara praktik manajemen laba dan return saham.

Perbedaan-perbedaan hasil penelitian yang telah dilakukan sebelumnya terkait dampak manajemen laba terhadap stock return menjadi salah satu motivasi dilakukannya penelitian ini. Tujuan dilakukannya penelitian ini adalah untuk menguji pengaruh manajemen laba yang diukur dengan akrual diskresioner terhadap return saham, dan menguji kemampuan pengawasan internal (melalui komite audit) dan pengawasan eksternal (melalui auditor independen) untuk memoderasi hubungan antara manajemen laba dan return saham. Pengawasan internal yang dilakukan oleh komite audit dan pengawasan eksternal yang dilakukan oleh auditor eksternal diharapkan mampu mengurangi pengaruh negatif yang terjadi antara praktik manajemen laba dan return saham. Pengawasan yang tinggi diharapkan mampu untuk mendeteksi dan mengurangi praktik manajemen laba yang bersifat oportunistik di dalam perusahaan. Sehingga informasi keuangan yang dihasilkan perusahaan dapat dipercaya oleh para investor dan mampu meningkatkan nilai dari perusahaan yang bersangkutan. Penelitian yang dilakukan oleh Gul, Lynn dan Tsui (2002), Krishnan (2003), Lin dan Hwang (2010), dan Nuryaman (2013) menemukan bahwa kualitas audit yang tinggi memiliki kemampuan untuk memoderasi hubungan negatif antara manajemen laba dengan return saham. Penelitian yang dilakukan Chung, Firth dan Kim (2002), Jaggi dan Tsui (2007), Siregar dan Utama (2008), dan Darwis (2012) terkait dengan peranan tata kelola perusahaan sebagai variabel moderasi hubungan manajemen laba dan return saham menemukan corporate governance mampu memoderasi hubungan antara manajemen laba dan nilai perusahaan.

Motivasi lain dilakukannya penelitian ini adalah pada penelitian-penelitian sebelumnya yang telah dilakukan di Indonesia belum banyak yang menganalisis peran dari komite audit sebagai mekanisme pengawasan internal dalam memoderasi hubungan antara manajemen laba dan stock return. Penelitian yang dilakukan sebelumnya lebih banyak menyoroti peran kualitas audit yang mencerminkan mekanisme pengawasan eksternal sebagai variabel pemoderasi, seperti penelitian Nuryaman (2013).

\section{Teori Keagenan (Agency Theory)}

Dalam kaitannya dengan manajemen laba, terdapat dua teori besar yang mendasarinya yaitu stewardship theory untuk manajemen laba yang bersifat efisien dan agency theory untuk mana- 
jemen laba yang bersifat oportunistik. Stewardship theory berpendapat bahwa manajer merupakan penjaga amanah yang baik sehingga praktik manajemen laba yang dilakukannya akan menguntungkan pemilik, sedangkan agency theory berpendapat terdapat perbedaan kepentingan antara manajer dan pemilik perusahaan. Penelitian yang dilakukan akan berfokus pada praktik manajemen laba yang bersifat oportunistik karena praktik manajemen laba yang umum terjadi, termasuk di Indonesia merupakan praktik manajemen laba oportunistik seperti diprediksi oleh teori keagenan (Gumanti 2004, Herawaty 2009, Ramdani dan Witteloostuijn 2010).

Agency theory merupakan suatu teori yang menjelaskan masalah keagenan yang timbul ketika pemilik perusahaan (principal) memberikan wewenang kepada manajemen (agent) (Jensen dan Meckling (1976)). Permasalahan muncul ketika agent memiliki kepetingan yang berbeda dengan principal yang kemudian disebut dengan agency problem. Agency problem kemudian akan memunculkan biaya keagenan atau yang biasa disebut dengan agency cost. Agency cost merupakan biaya yang harus dikeluarkan oleh perusahaan yang akan menurunkan kekayaan principal untuk memastikan bahwa agen bertindak sesuai dengan kepentingan principal. Salah satu baiya yang harus dikeluarkan adalah biaya pengawasan, baik pengawasan internal (misalnya melalui komite audit dan audit internal) maupun pengawasan eksternal (misalnya melalui audit eksternal).

\section{Stock Return}

Return (imbal hasil) merupakan suatu tingkat pengembalian hasil atau laba atas surat berharga maupun investasi modal yang dilakukan oleh pelaku investasi. Return saham merupakan imbal hasil yang diperoleh oleh pemegang saham atas hasil investasinya di perusahaan tertentu. Return dapat dibedakan menjadi realized return dan expected return. Realized return merupakan return aktual yang diperoleh investor pada periode investasi tertentum, sedangkan expected return merupakan return yang diharapkan oleh investor di masa datang atas investasi yang dilakukannya (Jones et. al, 2009). Expected return dapat dihitung dengan menggunakan beberapa pendekatan yaitu mean adjusted model, market model, dan market adjusted model. Dalam penelitian ini pendekatan yang digunakan untuk menghitung expected return adalah market adjusted model menggunakan Indeks Harga Saham Gabungan (IHSG).

Reaksi pasar atas informasi yang disampaikan oleh perusahaan termasuk informasi keuang- an yang disajikan dalam laporan keuangan ditunjukkan dengan adanya perubahan harga saham perusahaan yang bersangkutan. Reaksi ini dapat diukur dengan menggunakan return sebagai nilai perubahan harga atau dengan menggunakan return tidak normal (abnormal return). Abnormal return merupakan selisih dari return aktual dan return normal. Return normal merupakan return yang diharapkan oleh investor atau expected return. Penjumlahan dari abnormal return disebut Cumulative Abnormal Return (CAR).

\section{Manajemen Laba (Earnings Management)}

Manajemen laba dapat didefinisikan sebagai suatu tindakan yang dilakukan melalui pemilihan kebijakan akuntansi untuk memperoleh tujuan tertentu misalnya untuk meningkatkan nilai perusahaan atau untuk kepentingan pribadi manajemen perusahaan (Scott, 2011). Praktik manajemen laba memiliki dua sifat utama yaitu efisien dan oportunistik. Adanya praktik manajemen laba yang bersifat oportunistik sangat berkaitan erat dengan permasalahan keagenan dalam perusahaan. Permasalahan keagenan yang terjadi dalam perusahaan akan mendorong manajer sebagai agen melakukan praktik manajemen laba untuk memenuhi kepentingan pribadinya yang biasanya bertolak belakang dengan kepentingan principal.

Menurut Scott (2011) beberapa motivasi dilakukannya manajemen laba adalah rencana bonus, kontrak utang, motivasi politik, motivasi pajak, pergantian Chief Executive Officer (CEO), dan penawaran saham perdana (IPO). Beberapa pola manajemen laba menurut Scott (2011) adalah taking a bath, income minimization, income maximization, dan income smoothing. Pada awal tahun 1980-an, penelitian mengenai manajemen laba difokuskan pada faktor-faktor penentu dan dampak dari pilihan akuntansi wajib dan sukarela perusahaan (Watts and Zimmerman, 1986), namun sejak pertengahan tahun 1980-an fokus penelitian manajemen laba telah bergeser kepada akrual. Hal ini disebabkan karena digunakannya basis akrual dalam praktik akuntansi yang menimbulkan banyak permasalahan, salah satunya adanya akrual diskresioner yang akan menjadi proksi manajemen laba dalam penelitian yang dilakukan. Akrual diskresioner dalam penelitian ini digunakan untuk melihat besarnya manajemen laba yang bersifat oportunistik yang dilakukan oleh perusahaan.

Praktik manajemen laba oportunistik dapat menyebabkan investor membuat suatu keputusan investasi yang salah, karena informasi yang disajikan tidak menggambarkan keadaan dan posisi keuangan perusahaan yang sebenarnya. 
Tingginya tingkat manajemen laba oportunistik dalam perusahaan mengindikasikan tingginya risiko yang ada bagi investor, dan menyebabkan return yang akan diperoleh oleh investor lebih rendah. Tariq (2009) dan Nuryaman (2013) menemukan bahwa manajemen laba berpengaruh negatif terhadap abnormal return pasar. Kang, Liu dan Qi (2010) menyatakan bahwa aggregate discretionary accruals secara positif dapat memprediksi return pasar masa datang dan berhubungan negatif dengan return pasar saat ini. Namun hasil berbeda diperoleh oleh Ferdiansyah dan Purnamasari (2012) yang menemukan adanya hubungan positif signifikan antara manajemen laba dengan return saham. Berdasarkan prediksi teori keagenan yang melandasi penelitian ini, diduga manajemen laba yang bersifat oportunistik memiliki pengaruh negatif terhadap return saham perusahaan. Pada penelitian ini diambil data nilai absolut dari manajemen laba, tidak dibedakan antara manajemen laba yang menaikkan atau menurunkan laba. Berdasarkan hal tersebut, maka diajukan hipotesis sebagai berikut:

H1: Manajemen laba berpengaruh negatif terhadap stock return

\section{Kualitas Audit}

Audit merupakan kegiatan evaluasi bukti mengenai suatu informasi untuk menentukan dan melaporkan tingkat kesesuaian antara informasi dnegan kriteria yang telah ditetapkan (Arens et. al, 2009). Kualitas audit didefinisikan sebagai sebuah peluang dimana auditor eksternal dapat mendeteksi kesalahan dalam laporan keuangan dan kemudian melaporkannya kepada pengguna laporan keuangan (DeAngelo, 1981). Kualitas audit yang dihasilkan oleh auditor akan sangat bergantung pada kompetensi dan independensi yang dimiliki oleh auditor.

Kualitas audit secara utuh tidak dapat diwakilkan oleh karakteristik tertentu karena sifatnya yang multidimensi (Bamber dan Bamber, 2009; Francis, 2004). Pengukuran atas kualitas audit yang ada saat ini lebih banyak menggunakan pengukuran tunggal atau pengujian bersama dari beberapa pengukuran yang hanya mewakili satu dimensi dari kualitas audit, misalnya ukuran Kantor Akuntan Publik (KAP) (Becker et al., 1998; Reynolds dan Francis, 2001), spesialisasi industri (Balsam, Krishnan dan Yang, 2003), atau lamanya waktu penugasan audit (Gosh dan Moon, 2005). Penelitian ini menggunakan ukuran KAP sebagai proksi dari kualitas audit sebagaimana dikemukakan oleh DeAngelo (1981) dan Watts dan Zimmerman (1986) berpendapat bahwa ukuran auditor akan memiliki pengaruh positif terhadap kualitas audit.
Kualitas audit yang tinggi akan membuat laporan keuangan memiliki tingkat manajemen laba oportunistik yang rendah yang diekspektasi akan membuat reaksi positif di pasar, sehingga kualitas audit mampu memperlemah atau mengurangi hubungan negatif yang terjadi antara manajemen laba dengan return saham. Penelitian yang dilakukan oleh Nuryaman (2013) menemukan bahwa kualitas audit yang tinggi memiliki kemampuan untuk memoderasi hubungan negatif antara manajemen laba dengan return saham karena kualitas audit yang tinggi meningkatkan kepercayaan investor atas laporan keuangan yang dihasilkan perusahaan sehingga return saham dari perusahaan ikut dipengaruhi. Selain itu penelitian yang dilakukan oleh Herawaty (2008) juga menemukan jika kualitas audit merupakan variabel yang mampu memoderasi hubungan antara manajemen laba dengan nilai perusahaan. Berdasarkan hal tersebut, maka diajukan hipotesis sebagai berikut:

H2: Hubungan negatif antara manajemen laba (earnings management) dan stock return dapat dimoderasi oleh kualitas audit yang tinggi

\section{Komite Audit}

Komite audit adalah komite yang dibentuk dan bertanggung jawab kepada Dewan Komisaris dalam membantu melaksanakan tugas dan fungsi Dewan Komisaris (Bapepam, 2012). Komite audit memiliki peran yang cukup vital dalam proses terlaksananya tata kelola perusahaan yang baik. Peran utama dari komite audit dalam perusahaan adalah untuk membantu memastikan pelaporan keuangan perusahaan yang berkualitas tinggi. Komite audit dan dewan komisaris merupakan pihak yang melakukan pengwasan dan pengendalian untuk menciptakan keadilan, transparasi, akuntabilitas, dan resposibilitas yang merupakan empat faktor yang membuat laporan keuangan lebih berkualitas (Sulistyanto, 2008).

Dalam peraturan Bapepam IX.I.5 yang dikeluarkan oleh Badan Pengawas Pasar Modal atau yang saat ini dikenal dengan Otoritas Jasa Keuangan (OJK) pada tahun 2012, dinyatakan bila komite audit paling tidak harus melakukan rapat secara berkala minimal sebanyak empat kali dalam satu tahun atau tiga bulan sekali. Rapat berkala yang dilakukan oleh komite audit diharapkan mampu meningkatkan efektivitas dari fungsi komite audit dalam melakukan pengawasannya terhadap perusahaan. Jumlah rapat komite audit dalam satu tahun dijadikan sebagai proksi efektivitas komite audit dalam penelitian ini. Xie et al. (2003) menyatakan bahwa jumlah 
pertemuan komite audit memiliki hubungan negatif dengan manajemen laba. Vafeas (2005) menemukan ketika komite audit melakukan lebih banyak pertemuan dan pengamatan secara langsung, komite audit dapat mengurangi tingkat manajemen laba. Beasley et al. (2004) menemukan komite audit untuk perusahaan yang melakukan kesalahan dalam pelaporan keuangan memiliki frekuensi pertemuan lebih sedikit dari pada komite audit pada perusahaan yang tidak melakukan kesalahan. Dalam penelitian ini, efektivitas komite audit diukur dengan jumlah rapat yang dilakukan komite audit dalam satu tahun.

Efektivitas komite audit yang tinggi dalam sebuah perusahaan diharapkan dapat memberikan pengawasan yang lebih baik yang mampu meminimalkan tingkat manajemen laba dalam perusahaan, sehingga pasar cenderung bereaksi positif. Penelitian yang dilakukan (Darwis, 2012) terkait dengan peranan tata kelola perusahaan sebagai variabel moderasi hubungan manajemen laba dan return saham menemukan corporate governance mampu memoderasi hubungan antara manajemen laba dan nilai perusahaan. Berdasarkan hal tersebut, maka diajukan hipotesis sebagai berikut:

H3: Hubungan negatif antara manajemen laba (earnings management) dan stock return dapat dimoderasi oleh efektivitas komite audit yang tinggi

\section{METODE PENELITIAN}

\section{Pengukuran Variabel}

Variabel dependen yang digunakan dalam penelitian ini adalah stock return. Abnormal return digunakan sebagai indikator dari stock return. Persamaan yang digunakan untuk mencari abnormal return adalah sebagai berikut:

Keterangan:

$$
A R \mathrm{t}=R \mathrm{t}-E(R \mathrm{t})
$$

ARt : Abnormal return saham

$\mathrm{Rt} \quad$ : Actual return saham

$\mathrm{E}(\mathrm{Rt})$ : Return saham yang diekspektasikan

Persamaan yang digunakan untuk mencari actual return adalah sebagai berikut:

$$
R t=\frac{P t-P(\mathrm{t}-1)}{P(\mathrm{t}-1)}
$$

Pt : Harga saham perusahaan i, pada akhir bulan $\mathrm{t}$

$\mathrm{P}(\mathrm{t}-1)$ : Harga saham perusahaan i, pada akhir bulan sebelumnya $(\mathrm{t}-1)$

Persamaan yang digunakan untuk mencari expected return adalah sebagai berikut:

$$
E(R \mathrm{t})=\frac{I H S G \mathrm{t}-I H S G(\mathrm{t}-1)}{I H S G(\mathrm{t}-1)}
$$

IHSGt : Indeks harga saham gabungan pada bulan $\mathrm{t}$

IHSG (t-1) : Indeks harga saham gabungan pada bulan sebelumnya (t-1)

Dalam penelitian ini digunakan cummulative abnormal return (CAR) untuk mengetahui reaksi pasar atas pengumuman atau informasi laba yang dikeluarkan atau dipublikasikan oleh perusahaan dan dijadikan sebagai proksi dari stock return. CAR sendiri merupakan akumulasi dari abnormal return selama satu tahun (12 bulan). Penggunaan periode 12 bulan dalam menghitung imbal hasil saham kumulatif ini sama dengan yang digunakan oleh Subramanyam (1996), Ardiati (2003), dan Adhariani (2005); pada periode ini diharapkan para pelaku pasar telah mampu menangkap informasi yang berasal dari laporan keuangan yang telah diaudit. CAR dapat dicari dengan menggunakan persamaan berikut:

$$
\operatorname{CAR}(\mathrm{t} 1, \mathrm{t} 2)=\sum A R \mathrm{t} 1, \mathrm{t} 2
$$

Variabel independen yang digunakan adalah variabel manajemen laba yang diukur dari discretionary accruals. Pengukuran yang digunakan untuk discretionary accrual adalah model modifikasi Jones (modified Jones Model) dengan pendekatan cross-section yang dikembangkan oleh Dechow, Sloan, dan Sweeney (1995). Alasan dari penggunaan pengukuran ini adalah Dechow, Sloan dan Sweeney (1995) menemukan bahwa baik model Jones atau pun modifikasi model Jones memiliki kekuatan yang paling baik untuk mendeteksi manajemen laba karena memiliki standar eror paling kecil dibandingkan model-model lainnya. Persamaan-persamaan yang digunakan untuk mencari akrual diskresioner adalah sebagai berikut:

$$
\begin{aligned}
& D A t=\frac{T A C \mathrm{t}}{T A(\mathrm{t}-1)}-N D T C A \mathrm{t} . \\
& \frac{T A C t}{T A(t-1)}= \alpha 1\left[\frac{1}{T A(t-1)}\right]+\alpha 2\left[\frac{\triangle R E V t-\triangle R E C t}{T A(t-1)}\right]+ \\
& \alpha 3\left[\frac{P P E t}{T A(t-1)}\right]+\varepsilon \\
& N D T A C t= \alpha 1\left[\frac{1}{T A(t-1)}\right]+\alpha 2\left[\frac{\triangle R E V t-\triangle R E C t}{T A(t-1)}\right]+ \\
& \alpha 3\left[\frac{P P E t}{T A(t-1)}\right]
\end{aligned}
$$

Keterangan:

DAt : Abnormal accrual atau discretionary accrual, yang diperoleh dengan mengurangi total akrual dengan non-diskresioner akrual. Diskresioner Akrual inilah yang menggambarkan manajemen laba yang ada dalam perusahaan. 
TACt : TACt, merupakan total akrual perusahaan i, pada periode $\mathrm{t}$

NDTCAt: NDTACt, merupakan akrual nondiskresioner perusahaan i, pada tahun $\mathrm{t}$

TACt merupakan total akrual perusahaan i pada periode $t$, yang dihitung dengan mengurangi laba bersih setelah pajak dengan aliran kas operasi. Persamaan (2) diatas digunakan untuk mencari parameter spesifik perusahaan ( $\alpha 1, \alpha 2$, dan a3). Untuk memperoleh estimasi yang akurat, regresi terhadap persamaan (2) dilakukan pada masing-masing industri pada tiap tahunnya.

\section{Model Penelitian}

Dalam penelitian yang dilakukan, digunakan 3 model regresi untuk menguji 3 hipotesis yang diajukan, model-model tersebut adalah sebagai berikut:

Model 1: digunakan untuk menguji hipotesis 1

$$
\begin{aligned}
C A R \mathrm{i}, \mathrm{t}= & \beta 0+\beta 1(D A) \mathrm{i}, \mathrm{t}+\beta 2(L E V) \mathrm{i}, \mathrm{t} \\
& +\beta 3(P B V) \mathrm{i}, \mathrm{t}+\beta 4(R O A) \mathrm{i} . \mathrm{t}+\varepsilon
\end{aligned}
$$

Keterangan:

CAR : Cummulative abnormal return (imbal hasil saham kumlatif)

DA : Discretionary accrual, menggambarkan manajemen laba

LEV : Rasio leverage perusahaan i, pada periode $\mathrm{t}$, rasio leverage yang digunakan adalah debt to asset ratio

PBV : Price Book Value Ratio perusahaan i, pada periode t

ROA : Return On Asset perusahaan i, pada periode $\mathrm{t}$

$\varepsilon \quad:$ error

Model 2: digunakan untuk menguji hipotesis 2

$$
\begin{aligned}
C A R i, t= & \beta 0+\beta 5(D A) \mathrm{i}, \mathrm{t}+\beta 6(A U D) \mathrm{i}, \mathrm{t} \\
& +\beta 7(D A U D) \mathrm{i}, \mathrm{t}+\beta 8(L E V) \mathrm{i}, \mathrm{t} \\
& +\beta 9(P B V) \mathrm{i}, \mathrm{t}+\beta 10(R O A) \mathrm{i}, \mathrm{t}+\varepsilon
\end{aligned}
$$

Keterangan:

AUD : Kualitas audit yang diukur menggunakan variabel dummy KAP, 1 untuk KAP Big 4, dan 0 untuk KAP non-Big 4

D AUD : Interaksi variabel kualitas audit dengan manajemen laba

Model 3: digunakan untuk menguji hipotesis 3

$$
\begin{aligned}
C A R= & \beta 0+\beta 11(D A) \mathrm{i}, \mathrm{t}+\beta 12(\text { KOM }) \mathrm{i}, \mathrm{t} \\
& +\beta 13(D A K O M) \mathrm{i}, \mathrm{t}+\beta 14(L E V) \mathrm{i}, \mathrm{t} \\
& +\beta 15(P B V) \mathrm{i}, \mathrm{t}+\beta 16(R O A) \mathrm{i}, \mathrm{t}+\varepsilon
\end{aligned}
$$

Keterangan:

KOM : Komite audit, diukur dengan menggunakan jumlah rapat dalam satu tahun

DAKOM : Interaksi variabel komite audit dengan manajemen laba

\section{Pemilihan Sampel dan Pengumpulan Data}

Populasi dalam penelitian ini mencakup perusahaan manufaktur yang terdaftar dalam Bursa Efek Indonesia (BEI) sejak tahun 2012 hingga tahun 2014. Sampel yang digunakan dalam penelitian adalah perusahaan-perusahaan yang masuk kedalam industri manufaktur. Sampel dipilih dengan menggunakan metode purposive sampel dengan kriteria-kriteria sebagai berikut:

1. Perusahaan manufaktur yang tercatat di BEI pada tahun 2012 hingga tahun 2014. Pemilihan sampel hanya dibatasi pada perusahaan manufaktur karena untuk mendapatkan estimasi atau nilai discretionary accrual (DA) yang akurat perlu dilakukan regresi terhadap datadata TAC masing-masing industri pada masing-masing tahun dalam periode penelitian. Model estimasi discretionary accruals yang berlaku untuk perusahaan manufaktur ternyata tidak berlaku untuk perusahaan nonmanufaktur (Na'im \& Hartono, 1996). Untuk menghindari bias dalam menentukan estimasi discretionary accruals dan agar lebih terfokus, penelitian yang dilakukan hanya memilih industri manufaktur saja sebagai sampel.

2. Perusahaan melaporkan laporan keuangan yang telah diaudit dari tahun 2012 hingga tahun 2014

3. Data-data perusahaan yang dibutuhkan dalam penelitian ini tersedia

Dari pemilihan sampel yang dilakukan, diperoleh sampel sebanyak 275 untuk model penelitian 1 dan 2, dan 209 untuk model penelitian 3 untuk periode 2012-2014.

\section{HASIL PENELITIAN DAN PEMBAHASAN}

Statistik deskriptif dapat dilihat pada tabel 1, yang merupakan ringkasan statistik deskriptif dari variabel-variabel yang digunakan.

Variabel utama yang digunakan dalam penelitian ini adalah CAR dan DA. Dari hasil statistik deskriptif pada model 1 dan 2 terlihat jika CAR memiliki rata-rata sebesar 0.056 , nilai minimum 1.3036 dan nilai maksimum 6.4569. Hasil ini menunjukkan bila rata-rata tingkat abnormal return untuk saham-saham perusahaan manufaktur di Indonesia pada tahun 2012-2014 adalah sebesar 5.6\%. Hal tersebut artinya pada tahun 2012-2014, rata-rata saham perusahaan-perusahaan manufaktur menghasilkan return saham yang lebih tinggi dibandingkan dengan return pasarnya. Pada model 3, rata-rata perusahaan manufaktur memiliki tingkat abnormal return sebesar $2.1 \%$. Standar deviasi juga lebih besar dari nilai ratarata sehingga dapat dikatakan sampel yang digunakan memiliki data yang bervariasi atau tersebar. 
Tabel 1. Statistik Deskriptif

\begin{tabular}{|c|c|c|c|c|c|}
\hline \multicolumn{6}{|c|}{ MODEL 1 dan 2} \\
\hline Variabel & Obs & Mean & Standar Deviasi & Min. & Max. \\
\hline CAR & 275 & 0.0568 & 0.6543 & -1.036 & 6.4569 \\
\hline DA & 275 & 0.0059 & 0.4722 & -1.385 & 6.6642 \\
\hline AUD & 275 & 0.5090 & 0.5008 & 0 & 1 \\
\hline DAUD & 275 & -0.0229 & 0.1755 & -1.385 & 0.7510 \\
\hline LEV & 275 & 0.3014 & 0.4341 & 0 & 3.9863 \\
\hline PBV & 275 & 2.9921 & 7.126 & -31.36 & 53.5900 \\
\hline ROA & 275 & 0.0678 & 0.1174 & -0.2754 & 0.8421 \\
\hline \multicolumn{6}{|c|}{ MODEL 3} \\
\hline Variabel & Obs & Mean & Standar Deviasi & Min. & Max. \\
\hline CAR & 209 & 0.0210 & 0.4945 & -0.8629 & 3.0911 \\
\hline DA & 209 & -0.0205 & 0.2326 & -1.3855 & 0.9549 \\
\hline $\mathrm{KOM}$ & 209 & 8.0861 & 11.8468 & 1 & 96 \\
\hline DAKOM & 209 & -0.5747 & 5.7751 & -76.936 & 11.4589 \\
\hline LEV & 209 & 0.2610 & 0.2818 & 0 & 2.4882 \\
\hline PBV & 209 & 3.6698 & 7.6592 & -0.6188 & 53.5900 \\
\hline ROA & 209 & 0.0757 & 0.1195 & -0.2754 & 0.8421 \\
\hline \multicolumn{6}{|c|}{ Variabel Dummy } \\
\hline AUD & \multicolumn{3}{|c|}{$\begin{array}{c}\text { \% Nilai } 1 \\
50.90\end{array}$} & \multicolumn{2}{|c|}{$\begin{array}{c}\text { \% Nilai } 0 \\
49.10\end{array}$} \\
\hline \multicolumn{6}{|l|}{ Keterangan: } \\
\hline CAR & \multicolumn{5}{|c|}{ Cummulative Abnormal Return } \\
\hline DA & \multicolumn{5}{|c|}{ Discretionary Accrual } \\
\hline AUD & \multicolumn{5}{|c|}{ Kualitas Audit (dummy variabel, 1 ketika diaudit oleh Big 4 dan 0 ketika diaudit oleh KAP non-Big 4) } \\
\hline DAUD & \multicolumn{5}{|c|}{ Interaksi antara discretionary accruals dengan dummy kualitas audit } \\
\hline LEV & \multicolumn{5}{|c|}{ Debt to Asset Ratio } \\
\hline PBV & \multicolumn{5}{|c|}{ Price to Book Value Ratio } \\
\hline ROA & \multicolumn{5}{|c|}{ Return On Asset } \\
\hline KOM & \multicolumn{5}{|c|}{ Jumlah rapat komite audit dalam setahun } \\
\hline DAKOM & \multicolumn{5}{|c|}{ Interaksi antara discretionary accruals dengan jumlah rapat komite audit } \\
\hline
\end{tabular}

Selanjutnya untuk variabel DA, nilai ratarata sebesar 0.0059 yang berarti bahwa pada tahun 2012-2014 rata-rata perusahaan-perusahaan manufaktur di Indonesia melakukan manajemen laba dengan pola meningkatkan laba, karena nilai rata-rata menunjukkan angka yang positif. Data pada model 3 juga tidak jauh berbeda dengan model 1 dan 2. Untuk pengujian hipotesis, tidak dibedakan manajemen laba yang menaikkan atau menurunkan laba karena digunakan nilai absolut.

Variabel pemoderasi pertama yang digunakan dalam penelitian ini adalah kualitas audit yang diukur dengan menggunakan dummy ukuran KAP. Sebanyak 50.90\% sampel diaudit oleh KAP Big 4 dan sisanya sebesar $49.10 \%$ diaudit oleh non Big 4. Hasil ini mengindikasikan bila setengah dari perusahaan manufaktur yang dijadikan sampel telah menggunakan KAP besar seperti Big 4 untuk melakukan audit atas laporan keuangan perusahaannya. Hal ini juga dapat menjadi salah satu cara bagi perusahaan untuk menarik kepercayaan para pengguna laporan keuangan atas laporan keuangan yang dibuat oleh perusahaan.

Variabel pemoderasi kedua yang digunakan dalam penelitian ini adalah jumlah pertemuan atau rapat yang dilakukan komite audit perusahaan selama satu tahun. Dari tabel hasil statistik deskriptif model 3 dapat dilihat bahwa nilai minimum dari KOM adalah 1 dan nilai maksimumnya adalah 96. Hal ini menunjukkan bahwa masih terdapat perusahaan manufaktur di Indonesia yang belum mentaati peraturan Bapepam LK IX.I.5 yang menyebutkan bahwa komite audit perusahaan paling tidak harus melakukan pertemuan setiap tiga bulan sekali atau 4 kali dalam satu tahun. Tetapi pada kenyataannya masih terdapat perusahaan yang melakukan rapat di bawah jumlah yang telah ditetapkan tersebut.

Meskipun masih terdapat perusahaan yang belum mematuhi peraturan Bapepam, tetapi terdapat pula perusahaan manufaktur yang melakukan pertemuan komite audit jauh di atas angka yang telah ditetapkan. Yaitu sebanyak 8 kali dalam satu bulan atau sama dengan kurang lebih 96 kali pertemuan dalam satu tahun. Ratarata frekuensi pertemuan adalah sebesar 8.086, yang artinya secara rata-rata perusahaan-perusahaan manufaktur di Indonesia telah banyak yang mematuhi peraturan Bapepam dengan melakukan pertemuan komite audit paling tidak 4 kali dalam satu tahun. 
Tabel 2. Hasil Uji Regresi

\begin{tabular}{|c|c|c|c|c|}
\hline \multicolumn{5}{|c|}{ Hasil Regresi Model 1} \\
\hline \multirow{3}{*}{\multicolumn{5}{|c|}{$\begin{array}{l}\text { Hipotesis dan Model: } \\
\text { Hipotesis 1: Manajemen laba (DA) berpengaruh negatif terhadap stock return (CAR) } \\
\text { Model 1: CARit }=B 0+B 1 \text { (DA)it }+B 2(\text { LEV)it }+B 3(\text { PBV)it }+B 4(\text { ROA)it }+\varepsilon\end{array}$}} \\
\hline & & & & \\
\hline & & & & \\
\hline Variabel & Ekspektasi Hasil & Koef. & p-value & Signifikansi \\
\hline$\overline{\mathrm{DA}}$ & - & -0.3525 & 0.003 & $* * *$ \\
\hline LEV & - & -0.3091 & 0.027 & $* *$ \\
\hline PBV & + & 0.0231 & 0.062 & * \\
\hline $\mathrm{ROA}$ & + & 1.1905 & 0.009 & $* * *$ \\
\hline _Cons & & -0.0271 & 0.3515 & \\
\hline R Squared & $22.55 \%$ & & & \\
\hline Adj R Squared & $21.40 \%$ & & & \\
\hline \multirow[t]{2}{*}{ Prob $>$ F } & 0.000 & & & \\
\hline & & Regres & & \\
\hline
\end{tabular}

\section{Hipotesis dan Model}

Hipotesis 2: Hubungan negatif antara manajemen laba (earnings management) dan stock return dapat dimoderasi dengan kualitas audit tinggi

Model 2: CARit $=80$ + 85 (DA)it+ 86 (AUD)it + 87 (DAUD)it + 88 (LEV)it + 89 (PBV)it + 810 (ROA)it $+\varepsilon$

\begin{tabular}{|c|c|c|c|c|}
\hline Variabel & Ekspektasi Hasil & Koef. & p-value & Signifikansi \\
\hline$\overline{\mathrm{DA}}$ & - & -0.5899 & 0.0005 & $* * *$ \\
\hline AUD & + & 0.6448 & 0.082 & $*$ \\
\hline DAUD & + & 0.4442 & 0.023 & $* *$ \\
\hline LEV & - & -0.0330 & 0.459 & \\
\hline PBV & + & 0.0511 & 0.0005 & $* * *$ \\
\hline $\mathrm{ROA}$ & + & 3.5023 & 0.001 & $* * *$ \\
\hline Cons & & -0.6514 & 0.012 & \\
\hline R Squared & $25.93 \%$ & & & \\
\hline Adj R Squared & $24.30 \%$ & & & \\
\hline Prob > F & 0.000 & & & \\
\hline \multicolumn{5}{|l|}{ Keterangan: } \\
\hline \multicolumn{5}{|c|}{ : Discretionary Accrual (manajemen laba) } \\
\hline \multicolumn{5}{|c|}{ : Rasio Debt to Asset } \\
\hline \multicolumn{5}{|c|}{ : Kualitas Audit (dummy variabel, 1 ketika diaudit oleh Big 4) } \\
\hline \multicolumn{5}{|c|}{ : Interaksi antara discretionary accruals dengan dummy kualitas audit } \\
\hline \multicolumn{5}{|c|}{ : Rasio Price to Book Value } \\
\hline \multicolumn{5}{|c|}{ : Rasio Return On Asset } \\
\hline
\end{tabular}

\section{Hipotesis dan Model}

Hipotesis 3: Hubungan negatif antara manajemen laba (earnings management) dan stock return dapat dimoderasi dengan efektivitas komite audit yang tinggi

MODEL: CARit $=80+811$ (DA)it+ $812($ KOM)it $+813($ DAKOM $)$ it $+814(\mathrm{LEV})$ it $+815(\mathrm{PBV}) \mathrm{it}+816(\mathrm{ROA}) \mathrm{it}+\varepsilon$

\begin{tabular}{|c|c|c|c|c|}
\hline Variabel & Ekspektasi Hasil & Koef. & p-value & Signifikansi \\
\hline$\overline{\mathrm{DA}}$ & - & -0.8321 & 0.003 & $* * *$ \\
\hline KOM & + & -0.0022 & 0.259 & \\
\hline DAKOM & + & 0.0543 & 0.015 & $* *$ \\
\hline LEV & - & -0.0477 & 0.351 & \\
\hline PBV & + & 0.0284 & 0.001 & $* * *$ \\
\hline $\mathrm{ROA}$ & + & 0.5960 & 0.071 & * \\
\hline _Cons & & -0.0934 & 0.054 & * \\
\hline$\overline{\mathrm{R}}$ Squared & $23.08 \%$ & & & \\
\hline Adj R Squared & $20.80 \%$ & & & \\
\hline Prob $>$ F & 0.0001 & & & \\
\hline \\
\hline & & & & \\
\hline \multicolumn{2}{|c|}{$\begin{array}{l}\text { Keterangan: } \\
\text { DA : Discretionary Accrual (manajemen laba) }\end{array}$} & \multicolumn{3}{|c|}{ : Discretionary Accrual (manajemen laba) } \\
\hline Rasio & \multicolumn{4}{|c|}{ Rasio Debt to Asset } \\
\hline KOM : Jumla & \\
\hline DAKOM: Intera & tara discretionary a & ngan juml & te audit & : Jumlah rapat komite audit \\
\hline : Rasio & \multicolumn{4}{|c|}{$\begin{array}{l}\text { 1: Interaksi antara discretionary ac } \\
\text { : Rasio Price to Book Value }\end{array}$} \\
\hline ROA : Rasio & \multicolumn{4}{|c|}{ : Rasio Return On Asset } \\
\hline
\end{tabular}


Sebelum dilakukan uji regresi, data yang telah dikumpulkan terlebih dahulu melewati uji outlier. Uji outlier dilakukan untuk mengetahui apakah terdapat data yang memiliki karakteristik yang berbeda dengan yang lainnya. Dalam penelitian yang dilakukan treatment winzorize dipilih untuk menghilangkan data outlier. Berikut disajikan hasil pengujian tersebut.

\section{Hubungan Manajemen Laba dan Stock Return}

Pada tabel di atas dapat dilihat bila variabel DA memiliki nilai p-value yang lebih kecil dari $10 \%, 5 \%$, dan $1 \%$ dan memiliki koefisien negatif seperti arah yang diekspektasikan. Hasil yang diperoleh ini menandakan bahwa manajemen laba yang dilakukan oleh perusahaan akan berdampak negatif terhadap stock return dari perusahaan. Investor pada pasar modal Indonesia akan bereaksi negatif terhadap perusahaan yang melakukan manajemen laba sehingga harga saham dari perusahaan akan mengalami penurunan. Hal ini dikarenakan investor menghindari risiko pada perusahaan yang melakukan manajemen laba.

Tingginya tingkat manajemen laba dalam perusahaan akan membuat tingginya risiko yang harus dihadapi oleh investor. Hasil penelitian ini konsisten dengan hasil penelitian yang telah dilakukan oleh Nuryaman (2013) yang menyatakan manajemen laba yang dilakukan oleh perusahaan akan memiliki pengaruh negatif terhadap abnormal return saham perusahaan. Penelitian yang dilakukan oleh Baber, Chen, dan Kang (2006) juga menemukan hasil yang sama, yaitu manajemen laba berpengaruh secara signifikan dan negatif terhadap reaksi harga saham. Selain itu hasil penelitian ini juga sejalan dengan penelitian yang dilakukan oleh Kang, Liu dan Qi (2010) yang menyatakan bahwa discretionary accrual memiliki hubungan negatif dengan current market return. Namun hasil penelitian ini tidak sejalan dengan hasil penelitian yang dilakukan oleh Solechan (2009) yang menemukan bahwa akrual diskresioner tidak berpengaruh signifikan terhadap return saham.

Hasil dari penelitian ini juga dapat memberikan keyakinan bahwa para investor di pasar modal Indonesia sudah lebih banyak memperhatikan dan menganalisis laporan keuangan atau informasi keuangan yang dihasilkan oleh perusahaan untuk membuat keputusan investasinya. Atau secara konsep para investor Indonesia telah dapat disebut sebagai investor yang rasional. Investor yang rasional adalah investor yang melakukan analisis dalam proses pengambilan keputusan investasinya. Analisis yang dilakukan di antaranya dengan mempelajari laporan keuangan perusahaan, serta mengevaluasi kinerja bisnis perusahaan. Tujuan dilakukannya analisis adalah agar keputusan investasi yang dibuatnya mampu untuk memberikan pengembalian atau kepuasan yang optimal (Puspitaningtyas, 2013).

\section{Moderasi Variabel Kualitas Audit terhadap hubungan antara Manajemen Laba dan Stock Return}

Dalam penelitian ini kualitas audit dijadikan sebagai variabel pemoderasi pada hubungan DA dan CAR. Interaksi antara DA dan kualitas audit (AUD) dihasilkan dari perkalian antara DA dan AUD (DA*AUD) yang dilambangkan dengan DAUD. Pada tabel hasil uji dapat dilihat bila $p$ value yang dimiliki DAUD adalah sebesar 0.023 atau masih lebih rendah dari nilai a 5\% sehingga dengan tingkat keyakinan 95\% DAUD dapat memoderasi hubungan antara DA dan CAR. Arah yang dihasilkan adalah positif. Dengan kata lain DAUD sebagai variabel pemoderasi hubungan antara DA dan CAR mampu memoderasi hubungan negatif antara DA dan CAR.

Hasil ini mengindikasikan bahwa pasar akan lebih percaya pada perusahaan yang diaudit oleh KAP Big 4 karena memiliki kualitas laba yang tinggi, sehingga pasar akan bereaksi positif terhadap perusahaan yang diaudit oleh KAP Big 4; yang pada akhirnya akan meningkatkan nilai dari perusahaan tersebut. Sehingga hubungan negatif yang terjadi antara DA dan CAR akan menjadi lemah ketika perusahaan telah diaudit oleh KAP Big 4. Kualitas audit yang diberikan oleh KAP Big 4 mampu menurunkan praktik manajemen laba dan meningkatkan nilai dari perusahaan yang bersangkutan. Sehingga pengaruh negatif dari manajemen laba terhadap return saham dapat dikurangi atau diperlemah. Pengawasan ekternal yang dilakukan oleh auditor independen dengan kualitas yang tinggi akan mampu mengurangi agency cost yang terjadi di dalam perusahaan, sehingga meningkatkan nilai perusahaan.

Hasil penelitian ini mendukung penelitian yang telah dilakukan sebelumnya oleh Nuryaman (2013) yang menemukan bila kualitas audit dapat memoderasi hubungan negatif antara manajemen laba dan return saham. Hasil penelitian ini juga sejalan dengan hasil penelitian yang dilakukan oleh Ardiati (2005) dan juga Herawaty (2009) yang menemukan jika kualitas audit yang tinggi yang dihasilkan oleh KAP besar seperti Big 4 mampu memoderasi hubungan antara manajemen laba dan juga return saham. 


\section{Moderasi Variabel Efektivitas Komite Audit terhadap hubungan antara Manajemen Laba dan Stock Return}

DAKOM yang merupakan interaksi antara DA dan KOM memiliki nilai p-value sebesar 0.015 yang lebih rendah dari a $5 \%$ dan $10 \%$, dan koefisien memiliki arah yang positif. Dengan hasil tersebut dapat disimpulkan jika efektivitas komite audit yang diukur dengan menggunakan jumlah pertemuan atau rapat komite audit dalam satu tahun mampu untuk memoderasi hubungan antara manajemen laba dengan stock return. Efektivitas komite audit yang tinggi dapat memperlemah hubungan negatif yang terjadi antara manajemen laba dengan stock return.

Semakin tinggi efektivitas komite audit pada perusahaan akan membuat pengendalian ataupun pengawasan yang ada dalam perusahaan semakin baik, sehingga agency cost yang terjadi dapat berkurang dan nilai perusahaan akan mengalami peningkatan. Tingkat efektivitas komite audit yang tinggi akan mampu mengurangi pengelolaan laba oportunistik yang dilakukan di dalam perusahaan sehingga memicu investor bereaksi positif terhadap harga saham perusahaan.

\section{Hubungan variabel PBV, ROA dan LEV ter- hadap Stock Return}

Variabel-variabel kontrol yang digunakan dalam penelitian ini adalah PBV, ROA, dan LEV. PBV dan ROA memiliki hubungan yang signifikan terhadap CAR. Hasil ini ditunjukkan dari p-value PBV dan ROA yang lebih kecil dari nilai a 10\%, 5\% dan $1 \%$. Arah yang dihasilkan untuk PBV dan ROA adalah positif sesuai dengan yang diekspektasikan. Hasil penelitian ini konsisten dengan Silalahi (1991) dan Kennedy (2003) yang juga menemukan ROA secara simultan mempengaruhi fluktuasi harga saham. Sedangkan untuk PBV, hasil penelitian yang dilakukan juga mendukung hasil penelitian yang dilakukan oleh Senthilkumar (2009) dan Muid (2011) yang menemukan PBV memiliki hubungan positif signifikan terhadap imbal hasil saham yang diproksi dengan CAR.

Variabel LEV yang merupakan variabel kontrol ketiga yang digunakan menunjukkan hasil yang berbeda untuk model 1 dan model 2 dan 3 . Pada hasil regresi model 1 LEV menunjukkan hasil yang signifikan dengan arah negatif. Hasil ini mengindikasikan semakin tinggi utang yang dimiliki oleh perusahaan untuk membiayai asetnya akan berdampak pada penurunan return saham perusahaan. Hasil penelitian ini konsisten dengan hasil penelitian yang dilakukan oleh (Ngaisah, 2008) dan (Pribawanti, 2007) yang menemukan rasio debt to asset memiliki hubungan negatif signifikan terhadap return saham. Sedangkan pada hasil uji regresi model penelitian 2 dan 3, LEV menunjukkan hasil yang tidak signifikan. Dengan arah negatif, hasil ini menunjukkan jika pada model penelitian 2 dan 3 LEV tidak memiliki pengaruh terhadap return saham perusahaan.

\section{KESIMPULAN DAN SARAN}

Penelitian ini bertujuan untuk menganalisis pengaruh manajemen laba terhadap imbal hasil saham (stock return), dengan kualitas audit dan efektivitas komite audit sebagai variabel pemoderasi. Hasil penelitian menunjukkan bahwa praktik manajemen laba yang dilakukan oleh perusahaan berpengaruh negatif terhadap return saham perusahaan tersebut. Kualitas audit yang tinggi yang diberikan oleh KAP besar seperti Big 4 terbukti memiliki kemampuan untuk memoderasi (memperlemah) hubungan negatif antara manajemen laba dengan return saham.

Efektivitas komite audit yang tinggi yang dilakukan oleh komite audit perusahaan terbukti memiliki kemampuan untuk memoderasi hubungan negatif antara manajemen laba dengan return saham. Sehingga dapat disimpulkan jika hubungan negatif antara praktik manajemen laba dengan return saham mampu diperlemah dengan efektivitas komite audit yang tinggi.

Hasil penelitian ini mengindikasikan pentingnya peranan auditor dan komite audit dalam memperlemah pengaruh negatif manajemen laba terhadap imbal hasil saham. Implikasi hasil penelitian ini adalah kualitas audit dan auditor serta komite audit perlu terus ditingkatkan untuk mengurangi praktik manajemen laba sehingga menghasilkan kepercayaan investor yang tercemin dalam harga dan return saham perusahaan.

Penelitian ini memiliki beberapa keterbatasan yang perlu diperhatikan untuk penelitianpenelitian selanjutnya, antara lain:

1. Penelitian yang dilakukan hanya dibatasi pada industri manufaktur saja dan belum memasukkan industri lain ke dalam sampel penelitian ini.

2. Model yang digunakan untuk mengestimasi manajemen laba dalam penelitian ini menggunakan model modifikasi Jones Dechow, dan tidak melalui proses pengamatan dan perbandingan terhadap model mana yang paling tepat digunakan untuk kondisi di Indonesia.

3. Periode penelitian masih sangat singkat yaitu hanya 3 tahun, 2012 sampai dengan tahun 2014.

Untuk itu, saran yang dapat penulis berikan untuk penelitian selanjutnya adalah: 
1. Penelitian selanjutnya dapat menggunakan sampel lebih luas dari penelitian ini, misalnya dengan melakukan penelitian pada seluruh perusahaan yang terdaftar pada BEI tidak hanya pada industri manufaktur saja.

2. Penelitian selanjutnya diharapkan dapat melakukan perbandingan terlebih dahulu dalam memilih model untuk mengestimasi manajemen laba, atau menggunakan model estimasi manajemen laba yang lainnya.

3. Penelitian selanjutnya dapat menambahkan atau mengganti proksi dari kualitas audit, tidak hanya dengan menggunakan ukuran KAP saja, misalnya dengan menggunakan 2 atau lebih proksi untuk kualitas audit seperti spesialisasi auditor, independensi dan lain sebagainya.

4. Jangka waktu yang digunakan pada penelitian selanjutnya diharapkan dapat lebih diperpanjang misalnya periode penelitian 5 tahun atau lebih.

\section{DAFTAR PUSTAKA}

Adhariani, D. (2005). Tingkat Keluasan Pengungkapan Sukarela Dalam Laporan Tahunan dan Hubungannya dengan Current Earnings Response Coefficient (ERC). Jurnal Akuntansi dan Keuangan Indonesia, 24-57.

Ardiati, A. Y. (2003). Pengaruh Manajemen Laba Terhadap Return Saham dengan Kualitas Audit sebagai Variabel Pemoderasi. Simposium Nasional Akuntansi VI.

Arens, e. a. (2009). Auditing and Assurance Services An Integrated Approach (An Indonesian Adaptation). Singapore: Prentice Hall.

Baber, W. R., Chen, S., \& Kang, S. H. (2006). Stock price reaction to evidence of earnings management: Implications for supplementary financial disclosure. Review of Accounting Studies, 11(1), 5-19.

Balsam, S., Krishnan, J., \& Yang, J. S. (2003). Auditor industry specialization and earnings quality. Auditing: A Journal of Practice \& Theory, 22(2), 71-97.

Bamber, E. M., \& Bamber, L. S. (2009). Discussion of" Mandatory Audit Partner Rotation, Audit Quality, and Market Perception: Evidence from Taiwan". Contemporary Accounting Research, 26(2), 393-402.

Bapepam. (2012). Keputusan Ketua Badan Pemeriksa Pasar Modal No. KEP-643/BL/2012, (Bapepam LK IX.I.5)). Pembentukan dan Pedoman Pelaksanaan Kerja Komite Audit. Jakarta: Republik Indonesia.

Beasley, M. S., Carcello, J. V., Hermanson, D. R., \& Neal, T. L. (2009). The audit committee oversight process. Contemporary Accounting Research, 26(1), 65-122.

Becker, C. L., DeFond, M. L., Jiambalvo, J., \& Subramanyam, K. R. (1998). The effect of audit quality on earnings management. Contemporary accounting research, 15(1), 1-24.

Chandra, A. (2011). Pengaruh Efektivitas Komite Audit Terhadap Relevansi Nilai Laba Bersih dan Arus Kas Dari Kegiatan Operasi. Jakarta: Universitas Indonesia.

Chung, R., Firth, M., \& Kim, J. B. (2002). Institutional monitoring and opportunistic earnings management. Journal of corporate finance, 8(1), 29-48.

Darwis, H. (2012). Manajemen Laba Terhadap Nilai Perusahaan Dengan Corporate Governance Sebagai Pemoderasi. Jurnal Keuangan dan Perbankan, 16(1), 45-55.

DeAngelo, L. E. (1981). Auditor size and audit quality. Journal of accounting and economics, 3(3), 183-199.

Dechow, P. M., Sloan, R. G., \& Sweeney, A. P. (1995). Detecting earnings management. Accounting review, 193-225.

DuCharme, L. L., Malatesta, P. H., \& Sefcik, S. E. (2004). Earnings management, stock issues, and shareholder lawsuits. Journal of financial economics, 71(1), 27-49.

Ferdiansyah dan Purnamasari, D. 2012. Pengaruh Manajemen Laba Terhadap Return Saham dengan Kecerdasan Investor sebagai Variabel Moderating. Jurnal Sains Manajemen \& Akuntansi. Vol. IV no. 2/November/2012.

Francis, J. R. (2004). What do we know about audit quality? The British accounting review, 36(4), 345-368.

Godfrey, J. (2010). Accounting Theory, 7 Edition. John Wiley.

Ghosh, A., \& Moon, D. (2005). Auditor tenure and perceptions of audit quality. The Accounting Review, 80(2), 585-612.

Gul, F. A., Lynn, S. G., \& Tsui, J. S. (2002). Audit quality, management ownership, and the informativeness of accounting earnings. Journal of Accounting, Auditing \& Finance, 17(1), 25-49.

Gumanti, T. A. (2004). Earnings Management: Suatu Telaah Pustaka. Jurnal Akuntansi dan Keuangan, 2(2), 99-104.

Herawaty, V. (2009). Peran Praktek Corporate Governance Sebagai Moderating Variable dari Pengaruh Earnings Management Terhadap Nilai Perusahaan. Jurnal Akuntansi dan Keuangan, 10(2), 90-97.

Jaggi, B., \& Tsui, J. (2007). Insider trading, earnings management and corporate governance: empirical evidence based on Hong 
Kong firms. Journal of International Financial Management \& Accounting, 18(3), 192222.

Jensen, M. C., \& Meckling, W. H. (1976). Theory of the firm: Managerial behavior, agency costs and ownership structure. Journal of financial economics, 3(4), 305-360.

Jones, C. P., Utama, S., Frensidy, B., Ekaputra, I. A., \& Budiman, R. U. (2009). Investments: Analysis and Management (An Indonesian Adaptation), Tenth Edition. United States of America: John Wiley \& Sons, Inc.

Kang, Q., Liu, Q., \& Qi, R. (2010). Predicting stock market returns with aggregate discretionary accruals. Journal of Accounting Research, 48(4), 815-858.

Kennedy, P. S. J. (2003). Analisis Pengaruh dari ROA, ROE, EPS, Profit Margin, Asset TO, Rasio Leverage dan DER terhadap Return Saham Studi pada Saham-saham yang termasuk dalam LQ 45 di Bursa Efek Jakarta tahun 2001. Doctoral dissertation, Program Pascasarjana Fakultas Ekonomi Universitas Indonesia).

Krishnan, G. V. (2003). Does Big 6 auditor industry expertise constrain earnings management? Accounting horizons, 17, 1-16.

Lin, J. W., \& Hwang, M. I. (2010). Audit quality, corporate governance, and earnings management: A meta-analysis. International Journal of Auditing, 14(1), 57-77.

Muid, D. (2011). Pengaruh Corporate Social Responsibility terhadap Stock Return. Fokus Ekonomi, 6(1), 105-121.

Na'im. A dan Hartono, 1996, The Effect of Untitrust Investigations on Management of Earning: A Test on Political Cost Hyothesis. Kelola: Gadjah Mada University Business Review, 13/V, 126-141.

Ngaisah, S. (2008). Pengaruh rasio profitabilitas dan leverage terhadap return saham pada perusahaan yang terdaftar di JII tahun 20042006. Skripsi, Yogyakarta: UIN Sunan Kalijaga.

Nuryaman. (2013). The Influence of Earnings Management on Stock Return and The Role of Audit Quality as a Moderating Variable. International Journal of Trade, Economics and Finance.

Pribawanti, T. 2007. Analisis Pengaruh Rasio Keuangan Terhadap Total Return Saham Pada Perusahaan Industri Manufaktur yang Membagikan Deviden di Bursa Efek Jakarta. Penelitian. Semarang: Universitas Negeri Semarang.

Ramdani, D., \& Witteloostuijn, A. V. (2010). The impact of board independence and CEO duality on firm performance: A quantile regression analysis for Indonesia, Malaysia, South Korea and Thailand. British Journal of Management, 21(3), 607-627.

Reynolds, J. K., \& Francis, J. R. (2000). Does size matter? The influence of large clients on office-level auditor reporting decisions. Journal of accounting and economics, 30(3), 375400.

Scott, W. R. (2011). Financial Accounting Theory, 6 edition. United States: Pearson.

Senthilkumar, G. (2009). Behavior of stock return in size and market-to-book ratio - evidence from selected Indian Industries. International Research Journals of Finance and Economics, 33, 142-153

Silalahi, Donalson. 1991, Beberapa Faktor Yang Mempengaruhi Perubahan Harga Saham (Studi pada Pasar Modal Indonesia), Tesis, Program Pascasarjana Universitas Airlangga, Surabaya.

Siregar, S. V., \& Utama, S. (2008). Type of earnings management and the effect of ownership structure, firm size, and corporate-governance practices: Evidence from Indonesia. The International Journal of Accounting, 43(1), 1-27.

Solechan, A. (2009). Pengaruh Manajemen Laba dan Earning terhadap Return saham (Studi Empiris pada perusahaan yang go public di BEI tahun 2003-2006, Doctoral dissertation, Universitas Diponegoro.

Subramanyam, K. R. (1996). The pricing of discretionary accruals. Journal of accounting and economics, 22(1), 249-281.

Sulistyanto, S. (2008). Manajemen Laba (Teori \& Model Empiris). Jakarta: Grasindo.

Tariq, N. (2009). Pengaruh praktik earnings management terhadap abnormal return saham (Doctoral dissertation, Universitas Widyatama).

Teoh, S., \& Wong, T. (1993). Perceived Auditor Quality and Earnings Response Coefficient. The Accounting Review, 346-367.

Teoh, S. H., Welch, I., \& Wong, T. J. (1998). Earnings management and the long-run market performance of initial public offerings. The Journal of Finance, 53(6), 1935-1974.

Vafeas, N. (2005). Audit committees, boards, and the quality of reported earnings. Contemporary accounting research, 22(4), 1093-1122.

Watts, R., \& Zimmerman, J. (1986). Positive theory of accounting. Englewood Cliffs, NY: PrenticeHall.

Xie, B., Davidson, W. N., \& Dadalt, P. J. (2003). Earnings Management Corporate Governance: The Roles of The Board and The Audit Committee. Journal of Corporate Finance, 295-316 